\title{
Persistence of quarterly earnings: an empirical investigation in Brazil
}

\author{
Renê Coppe Pimentel ${ }^{\dagger}$ \\ Fucape Business School
}

\author{
Andson Braga de Aguiar ${ }^{\Omega}$
}

Universidade de São Paulo

\begin{abstract}
The aim of this paper is to estimate and analyze quarterly earnings persistence. In addition, we explore if earnings persistence varies across firms based on size and corporate governance standards. We first estimate the parameter revision of earnings and then we test the hypotheses that the parameter of earnings persistence is different for firms with different sizes ( $\mathrm{H} 1)$ and corporate governance standards (H2). We collect data from Brazilian listed firms with quarterly earnings per share available at Economatica database from last quarter of 1995 to first quarter 2011. Our results indicate that for most of the firms the earnings persistence is not significantly different from zero. The main implication of this result is that most of quarterly earnings innovation is transitory. In addition, the results support our first hypothesis indicating that larger firms present higher parameter of earnings persistence. The results also indicate that the parameter of earnings persistence is different for firms with different corporate governance standards, partially supporting our second hypothesis.
\end{abstract}

Keywords: Earnings persistence; quarterly earnings; firm size; corporate governance standards; brazilian firms.

\footnotetext{
* Author for correspondence:

$\dagger P h D$ in Accounting at the University of São Paulo.

${ }^{\Omega} \mathrm{PhD}$ in Accounting at the University of São Paulo.

Affiliation: Associate Professor Fucape Business School. Affiliation:: Professor at the University

São Paulo.

Address: Av Luciano Gualberto, 908, Cidade Universitária, São Paulo -

Address: Av. Fernando Ferrari, 1358, Boa Vista,

SP - Brazil. CEP: 05508-010.

Vitória - ES - Brazil, CEP: 29075-505.

E-mail: abraga@usp.br

E-mail: renecp@fucape.br

Telephone: (27) 4009-4444

Telephone: (11) 30915820

Note from the Editor: This article was accepted by Bruno Funchal. 


\section{INTRODUCTION}

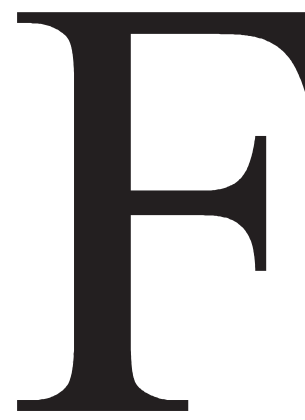

oster (1977) has been cited in a large number of studies relating accounting and financial literature, since it introduced an alternative way to evaluate earnings expectation models, namely contemporaneous market association of abnormal returns with 'earnings surprise', conditional upon the expectation model. He claims that, given the maintained hypothesis of an efficient market,

the strength of association between abnormal returns and earnings surprise indicates how accurately the model captures the market's expectation. According to Brown (1993), since the capital markets literature requires a proxy for the market's earnings expectation, the association approach made the earnings forecasting literature important for capital markets research, especially when abnormal returns are measured over a narrow window.

In this regard, earnings persistence represents the effect of earnings innovations on expected future earnings which helps to explain the relation between earnings and firm valuation (Kormendi \& Lipe, 1987). The concept of earnings innovation has relevant implication for the accounting literature as it allows the use of accounting information for valuation purposes, given the time-series behavior of abnormal earnings (Ohlson, 1995).

Prior international research (see Baginski et al, 2003 for citations) has documented an inter-temporal decline in earnings relevance for equity investors (i.e. decline in the persistence of quarterly accounting earnings), although, few studies have focused in quarterly earnings persistence estimation and the appropriate explanation for why persistence decline over time and the cross-sectional determinants of firm-specific persistence.

In this sense, this paper aims to estimate and analyze the quarterly earnings persistence for a set of Brazilian companies with minimum data available during the period of 1995 and 2010. Based on previous empirical findings, this paper also explores the reasons why persistence varies across firms by using measures of size and corporate governance standards (Kormendi \& Lipe, 1987; Baginski et al, 1999; Zhao \& MilletReyes, 2007).

The motivation of this paper relies on the relative importance of the Brazilian stock market, what can be attested by the high number of IPOs - Initial Public Offerings - from year 2004 to 2008 and the recent capital market growth. As a consequence, the role of 
accounting information might have an increased importance for investors in this setting. On the other hand, from the universe of Brazilian-listed companies, few firms have formal (and higher) corporate governance standards, what can raise questions about the quality of accounting information, more specifically, earnings innovation. Additionally, the Brazilian-listed companies are also characterized by very concentrated ownership and control, what can lead to a smaller free-float and lower trading activity (Silva and Subrahmanyam, 2007), reducing the importance of accounting information for capital market agents.

Given the contradictions between capital market growth and poor corporate governance standards for most listed companies, the contributions of this paper are threefold. First, we shed additional light on the issue of earnings quality by estimating quarterly earnings persistence (i.e. quarterly earnings innovation), since prior accounting literature has acknowledged that more persistent earnings will yield better inputs to equity valuation models, and hence a more persistent earnings number is of higher quality than a less persistent earnings number (Dechow, Ge \& Schrand, 2010). Second, we apply an imposed first-order autocorrelation model on the time-series of seasonally differenced earnings based on Foster (1977), since this model is a simple and at the same time it seems to perform just as well as the more complicated models (Kothari, 2001). Third, few studies in international literature estimate quarterly earnings persistence and, to our knowledge, only Coelho, Aguiar and Lopes (2011) has explicitly investigated earnings persistence in the Brazilian market, focusing on annual abnormal earnings, industry structure, and market share.

The remainder of the paper is outlined as follows. Section 2 examines the implication of earnings persistence to accounting information, reviews the literature of interest and develops the econometric model. Section 3 presents our data, empirical findings and discusses the results. Section 4 offers some concluding remarks.

\section{CONCEPTUAL FRAMEWORK AND MODEL SPECIFICATION}

Innovation in earnings, that is new information in earnings, is expected to be either permanent or transitory. Permanent earnings innovation means that earnings follow a random walk process, whereas transitory earnings innovation follows a mean reverting process (Baber, Kang, \& Kumar, 1998). In other words, permanent earnings innovation indicates that a shock in current earnings will affect expected future earnings. On the other 
hand, transitory earnings innovation will not help to explain expected future earnings as its effects will not persist over time.

The magnitude of the effect of permanent earnings innovations on expected future earnings is defined as earnings persistence; this parameter helps to explain the relation between earnings and firm valuation (Kormendi \& Lipe, 1987). More generally, previous studies have emphasized the two roles that earnings persistence can play: in valuation and stewardship settings (Christensen, Feltham, \& Şabac, 2005).

Persistent earnings have been acknowledged as valuable from a firm value forecasting perspective. For instance, Kormendi and Lipe (1987) mention that earnings persistence can explain the effect of earnings innovation on stock returns. Lipe (1990) offers additional evidence of the valuation role of earnings persistence by showing that the stock return reaction to earnings is increasing in the time-series persistence of the earnings series.

Valuation models have also been developed in which the parameter of earnings persistence play an important role to predict firm value. Ohlson's valuation model (1995) states that firm value is influenced by abnormal earnings; in turn, abnormal earnings follow an autoregressive process in which the parameter of earnings persistence indicates how sensitive the firm value is to earnings realization. Dechow, Ge \& Schrand (2010) suggest that firms with more persistent earnings have a more "sustainable" earnings/cash flow stream that will make it a more useful input into equity valuations models.

Earnings persistence has also been indicated to be used as a performance measure that can better mitigate the horizon problem in comparison to current earnings. The horizon problem involves actions that sacrifice long-term profitability for short-term profit gains (Dechow \& Sloan, 1991). Baber, Kang and Kumar (1998) show that in order to mitigate the horizon problem compensation committees adjust current-period earnings innovations to their persistence into the future when rewarding managers based on earnings. Şabac (2008) develop a multi-period agency model to show that the use of persistent earnings lead managers approaching retirement to increase their effort and effective incentive rates - defined as the sensitivities of aggregate compensation over a manager's tenure to performance.

Earnings persistence - in cases of measuring earnings innovation, measuring earnings quality, or measuring the horizon problem - is generally estimated based on 
annual earnings. However, estimations based on quarterly earnings have been indicated as more accurate and timely than those based on annual earnings. Precisely, Kothari (2001, p. 148) states that the interest in the time-series properties of quarterly earnings arises for at least four reasons: (1) quarterly earnings are seasonal in many industries because of the seasonal nature of their main business activity; (2) quarterly earnings are more timely, so the use of a quarterly earnings forecast as a proxy for the market's expectation is likely to be more accurate than using a stale annual earnings forecast; (3) GAAP requires that the quarterly reporting period is viewed as an integral part of the annual reporting period. As a result, firms are required to estimate annual operating expenses and allocate these costs to quarterly periods. More importantly, quarterly earnings are potentially a more powerful setting to test positive accounting theory based and capital markets research hypothesis; (4) there are four times more quarterly earnings than annual earnings observations. That means that less stringent data availability requirements are necessary using quarterly than annual earnings to achieve the same degree of precision of the forecasts.

Foster (1977) indicates some issues regarding quarterly accounting reports. The first concerns seasonal operations that, according to him, require a variety of adjustment techniques to reduce the effect of seasonality. Then, time-series analysis should provide important information for evaluating these techniques for seasonally adjusting quarterly earnings. Baginski et al. (1999) emphasize that time-series modelling assumptions can create significant differences in revision parameter estimates (persistence), and lead to different economic conclusions about persistence. This consideration makes an empirical issue in estimating persistence and analysing its determinants.

Market-based accounting literature has working with some well-developed BoxJenkins autoregressive integrated moving average (ARIMA) models to deal with quarterly earnings estimation. In this context, Foster's (1977) model has been highlighted as one of the most popular ARIMA structure since it is estimated in a simple form and does not require a specific statistical packed. However, even though the model is simple, it seems to perform just as well as the more complicated models (Kothari, 2001).

The model proposed by Foster (1977) was built under the strong assumption that an $\mathrm{AR}(1)$ process describes the time-series behaviour of the fourth difference in a quarterly data of all firms. Hence, Foster's (1977) model became a popular (1.0.0) x (0.1.0) with drift ARIMA structure of quarterly earnings for estimating persistence parameters and forecast earnings. It means that model is estimated by a first-order autoregressive 
approach, determined after seasonally differencing the time-series of quarterly earnings numbers (Brown, 1993). Foster's (1977) quarterly earnings model can be described as:

$$
E\left(X_{t}\right)=X_{t-4}+\Theta_{1}\left(X_{t-1}-X_{t-5}\right)+\delta
$$

Where, the expected earnings on quarter $t, E\left(X_{t}\right)$, is given by the same quarter of previous year (allowing for seasonality variances) and the parameter, $\Theta_{j 1}$, is given by the first order autocorrelation coefficient $\left(r_{l}\right)$. The drift term, $\delta$, is the average change in quarter which has occurred over the available historical data. A preliminary estimate of $\delta$ is given by $\left(1-\Theta_{j 1}\right) \cdot u$, where $u$ is the mean of the seasonality differenced series (Foster, 1977). The seasonal approach might be appropriate since Pimentel and Lima (2010) finds strong evidence of seasonality in quarterly accounting earnings in Brazil.

Easton and Zmijewski (1989), one of the most cited papers in estimating the quarterly persistence, consider Foster (1977)'s model for estimating the coefficient relating firm-specific past earnings to current earnings by:

$$
X_{j t}-X_{j t-4}=\Theta_{j 0}+\Theta_{j 1}\left(X_{j t-1}-X_{j t-5}\right)+u_{j t}
$$

Where, $X_{j t}$ is the quarterly accounting earnings of firm $j$ at quarter $t$, and $\Theta_{j 0}$ and $\Theta_{j 1}$ are firm-specific regression coefficient and $u_{j t}$ is a normally distributed term.

According to Easton and Zmijewski (1989), the parameter $\Theta_{j 1}$ can be interpreted as the magnitude of the next quarter earnings revision given a $\$ 1.00$ shock in current earnings (i.e. a parameter of 0.80 indicates that a $\$ 1.00$ shock in this quarter's earnings results in a \$ 0.80 revision in next quarter's earnings). In this sense, Miller and Rock (1985) refer to the extent to which the information in an earnings announcement results in a revision in expected earnings (the revision parameter) as 'persistence'.

In an analogous form, Baginski et al (2003) estimate persistence by combining the autoregressive parameter to obtain the persistence factor for Foster model; nevertheless, they improve the model by using a risk free interest rate as a discount rate for the present value of future revision parameters. This form of persistence measure is also used in annual data by the seminal paper of Kormendi and Lipe (1987). By analysing relationships between economic factors and earnings time-series behaviour, derived from the economic literature. Lev (1983) documents that earnings processes are weak when persistence 
metrics from lower-order time series models are used, but is higher when the measure of persistence is based on a differenced, higher order model.

After estimation of persistence parameters, it should be of interest to investigate the nature of differences in persistence parameters between firms. Kormendi and Lipe (1987), Easton and Zmijewski (1989), Collins and Kothari (1989) and other studies (see Dechow, Ge \& Schrand, 2010 for additional reference) consider size as one of the most important determinant of the accounting criteria quality and its relation with capital market, in special in terms of analysts coverage and political costs. Hence, size is a proxy for information environment differences and these differences in information environment affect the extent to which market anticipate earnings changes.

Collins and Kothari (1989, p.145) broadly define information environment to include all sources of information relevant to assessing firm value, including: government reports on macroeconomic conditions, industry reports and trade association publications, firm-specific news in the financial press and reports issued by analysts and brokerage houses in addition to accounting reports, and vertical and intra-industry information transfers via sales and industry reports.

Thus, according with previous literature, we hypothesize that persistence parameter can vary over different firm size and larger companies should present higher persistence parameter. Formally, we predict our first hypothesis as follows:

H1: The parameter of earnings persistence will be different for firms with different sizes, so that the larger the company, the higher its persistence parameter.

We also hypothesize that persistence parameter can vary over different level (standards) of corporate governance practices. Companies with higher levels of corporate governance might have higher persistence parameters, once they can have better relation with market investors and must have higher levels of disclosure and public information. Zhao and Millet-Reyes (2007) indicate that firms suffering more pressure from stock market to report timely and relevant earnings to outside investors also generate higher earnings persistence.

Therefore, we predict our second hypothesis as follows:

H2: The parameter of earnings persistence will be different for firms with different corporate governance standards, so that the higher the corporate governance standard, the higher the persistence parameter. 


\section{DATA AND EMPIRICAL FINDINGS}

Data in this study consist on all Brazilian listed firms with continuous series of a minimum of 24 quarterly earnings per share (6 years) available at Economatica database from last quarter of 1995 to first quarter 2011. Thus, our sample consists of 271 companies that satisfied the sample criteria and presented data ranging from 24 to 62 time-series observation. Hence, this set provides us 12,302 firm-quarter observations. Table 1 shows the number of companies distributed by economic sector (the complete list of companies and estimation outputs are available from authors under request).

The minimum of 24 continuous earning series is enough for persistence estimation. Easton and Zmijewski (1989), for instance, work with 20 quarterly observations. Using the criterion of minimum observation, our sample does not induce to a survivorship bias since we do not impose a complete lengthy time-series data requirement on our sample firms. Moreover, this choice of research design (i.e. firm-specific time-series) allows us to provide an important triangulation on cross-sectional research findings on earnings persistence.

Table 1: Companies by economic sector and corporate governance level ${ }^{\mathrm{a}}$

\begin{tabular}{|c|c|c|c|c|c|c|}
\hline Sector & NM & N1 & $\mathbf{N 2}$ & Trad. & Total & $\%$ \\
\hline Energy & 3 & 4 & 1 & 24 & 32 & $12 \%$ \\
\hline Textile & - & 6 & - & 19 & 25 & $9 \%$ \\
\hline Steel and metallurgic & 2 & 2 & - & 21 & 25 & $9 \%$ \\
\hline Telecommunications & - & - & - & 21 & 21 & $8 \%$ \\
\hline Finance and banking & 2 & 3 & - & 15 & 20 & $7 \%$ \\
\hline Food and beverage & 1 & 1 & - & 17 & 19 & $7 \%$ \\
\hline Vehicles and components & 3 & 2 & 1 & 8 & 14 & $5 \%$ \\
\hline Commerce & 2 & 1 & - & 10 & 13 & $5 \%$ \\
\hline Chemistry & 1 & 2 & - & 9 & 12 & $4 \%$ \\
\hline Real state & 2 & 0 & - & 9 & 11 & $4 \%$ \\
\hline Transport & 5 & 0 & 2 & 4 & 11 & $4 \%$ \\
\hline Other & 9 & 6 & 2 & 51 & 68 & $25 \%$ \\
\hline \multirow[t]{2}{*}{ TOTAL } & 30 & 27 & 6 & 208 & 271 & $100 \%$ \\
\hline & $11 \%$ & $10 \%$ & $2 \%$ & $77 \%$ & $100 \%$ & \\
\hline
\end{tabular}

${ }^{a} \mathrm{NM}$ is the new market, the most advanced corporate governance practices level. N1 is the second most advanced level of corporate governance. N2 is the less advanced corporate governance levels. Trad. is the traditional listing process with few (or no) corporate governance practices.

\subsection{Estimation of revision parameter}

Our first step is to empirically estimate the parameter revision of earnings based on Forster's (1977) time-series model for firm-specific quarterly earnings relating current to future earnings. We estimate the 271 firm-specific parameters using Eq. 2 and results are 
presented on Table 2, which shows the distributional characteristics of the time-series parameters.

Table 2: Distributional characteristics of the coefficients of the time-series process for earnings a

\begin{tabular}{|c|c|c|}
\hline & \multicolumn{2}{|l|}{$\left.X_{j t}-X_{j t-4}=\Theta_{j 0}+\Theta_{j 1} \backslash \Lambda_{j t-1}-\Lambda_{j t-5}\right) \top u_{j t}$} \\
\hline & $\Theta_{j 0}$ & $\Theta_{j 1}$ \\
\hline Mean & 0.0367 & 0.1909 \\
\hline Standard deviation & 0.5721 & 0.2504 \\
\hline Minimum & -5.2680 & -0.4335 \\
\hline $25^{\text {th }}$ Percentile & -0.0011 & 0.0208 \\
\hline Median & 0.0078 & 0.1922 \\
\hline $25^{\text {th }}$ Percentile & 0.0392 & 0.3664 \\
\hline Maximum & 5.0055 & 0.7451 \\
\hline Skewness & -0.8333 & -0.1921 \\
\hline Kurtosis & 55.4520 & 2.7790 \\
\hline Jarque-Bera & 31097.15 & 2.22 \\
\hline
\end{tabular}

The mean intercept, $\Theta_{j 0}$, is 0.0367 and its standard deviation is 0.5721 , thus, differently from Easton and Zmijewski (1989), we cannot infer that the intercept is reliably greater than zero for the entire sample. This conclusion is also valid by analyzing the firmspecific coefficients since only 15 firms presented intercept which is significantly different from zero: 3 firms rejected the null hypothesis at 1\% level, 8 firms at 5\% level and 4 firms at $10 \%$ level.

The mean coefficient relating current earnings to future earnings, $\Theta_{j 1}$, is 0.1909 and its standard deviation is 0.2504 . Jarque-Bera test $(\mathrm{JB}=2.2186)$ indicates that the estimated parameters follow normal distribution with Skewness of -0.1921 and Kurtosis 2.7790. In that sense, the mean coefficient of 0.1909 , in Table 2 , can be interpreted as, in average, a $\mathrm{R} \$ 1.00$ shock in this quarter's earnings results in a $\mathrm{R} \$ 0.19$ revision in next quarter's earnings.

Once again, differently from Easton and Zmijewski (1989), we cannot infer that the autoregressive coefficient is reliably greater than zero at $10 \%$ level for all sample. However, our results can be compared to those in Easton and Zmijewski (1989), for the American companies, since the mean of their 206 firms' coefficient was 0.486 , indicating a 
$\$ 0.486$ earnings revision for a $\$ 1.00$ previous period shock. This evidence indicates a lower relevance of past earnings to forecast future earnings in the Brazilian market.

Focusing on firm specific coefficients, it is possible to find 118 coefficients that are reliably different from zero at 10\% level, where 107 are greater than zero and 11 are, puzzling, significantly lower than zero. Table 3, resume the numbers of firm specific intercept and coefficient that are considered statistically significant (or not) at $1 \%, 5 \%$ and $10 \%$ level.

Table 3: Number of companies with significantly intercept and coefficients

\begin{tabular}{|c|c|c|c|c|c|c|c|c|}
\hline & \multicolumn{4}{|c|}{ Intercept - $\Theta_{j 0}$} & \multicolumn{4}{|c|}{ Coefficient $-\Theta_{j 1}$} \\
\hline & $\begin{array}{c}\text { Lower } \\
\text { than } \\
\text { zero }\end{array}$ & $\begin{array}{c}\text { Higher } \\
\text { than } \\
\text { zero }\end{array}$ & Total & $\%$ & $\begin{array}{l}\text { Lower } \\
\text { than } \\
\text { zero }\end{array}$ & $\begin{array}{c}\text { Higher } \\
\text { than } \\
\text { zero }\end{array}$ & Total & $\%$ \\
\hline Significant at $1 \%$ & 2 & 1 & 3 & $1 \%$ & - & 47 & 47 & 17 \\
\hline Significant at $5 \%$ & - & 8 & 8 & $3 \%$ & 8 & 37 & 45 & $17 \%$ \\
\hline Significant at $10 \%$ & - & 4 & 4 & $1 \%$ & 3 & 23 & 26 & $10 \%$ \\
\hline Total & 2 & 13 & 15 & $5 \%$ & 11 & 107 & 118 & $44 \%$ \\
\hline Not different from zero & & & 256 & $95 \%$ & & & 153 & $56 \%$ \\
\hline Entire sample & & & 271 & $100 \%$ & & & 271 & $100 \%$ \\
\hline
\end{tabular}

Intercept $\Theta_{j 0}$ and coefficient $\Theta_{j 1}$ are the parameters estimated in earnings firm-specific regressions of Eq. (2) $\quad X_{j t}-X_{j t-4}=\Theta_{j 0}+\Theta_{j 1}\left(X_{j t-1}-X_{j t-5}\right)+u_{j t}$

Regarding the large number of coefficients (153 firms or $56 \%$ from total) nondifferent from zero, it can be interpreted as if the firm's time-series of earnings do not present persistence (or revision parameter is close to zero); in other words, for this set of 153 companies, a shock in earnings in a given quarter does not result in significant revision for next quarters.

The empirical evidence of lower relevance of earnings can have at least four possible explanations. First, the quarterly earnings forecast model of Foster (1977) might not perform as well as it does in other markets; in this case, time-series of quarterly earnings in Brazil might not be described as a seasonal AR(1) model. Second, accounting earnings of Brazilian firms could be strongly affected by macroeconomic instability during this period (1995-2011) since economic variables induce variation in earnings generating increases or decreases in earnings that are merely transitory for some specific periods. Third, accounting standards or changes in accounting choices can reduce the persistence of earnings. Fourth, Brazilian managers and investors can have a focus on short-term earnings; hence, managers can manage earnings to produce more transitory (short-term) earnings rather than persistent and long-term earnings. 
Based on the considerable variability in firm-specific quarterly earnings persistence documented, this topic should be of interest to standard setters when they consider alternative reporting standards that might have an impact on firms' earnings persistence. Increasing the predictive ability of accounting should be one of the main efforts to bring efficiency to capital market.

We consider the statistical significance of negative coefficients puzzling for the research since it means that an increasing in earnings in a given quarter should induces a decrease in future earnings and vice-versa. In order to bring some light to this issue, we analyze separately the firms with significant negative parameters.

For the 11 firms with negative and significant coefficient, it was possible to find three main reasons for the negative parameters. The first reason is that in some cases, when earnings of operational activity fall in one quarter (or during a year) managers act in direction of re-balance firms accounting in the sense of compensating past losses with future profits. The second reason is that, for long periods, earnings seem to be constant or without growth; in these cases, earnings seem to follow a moving average behavior. The third reason is related to the implication of macroeconomic factors in earnings, since some companies faced during the period of 2002 and 2003 strong earnings instability derived from economic crisis. In addition firms with long-term negative earnings (losses) should return negative coefficients. To illustrate these cases of negative parameters, Figure 1 presents graphically the earnings time-series behavior for four out of 11 companies with negative parameters. Graphically presentation of all negative companies is available under request. 


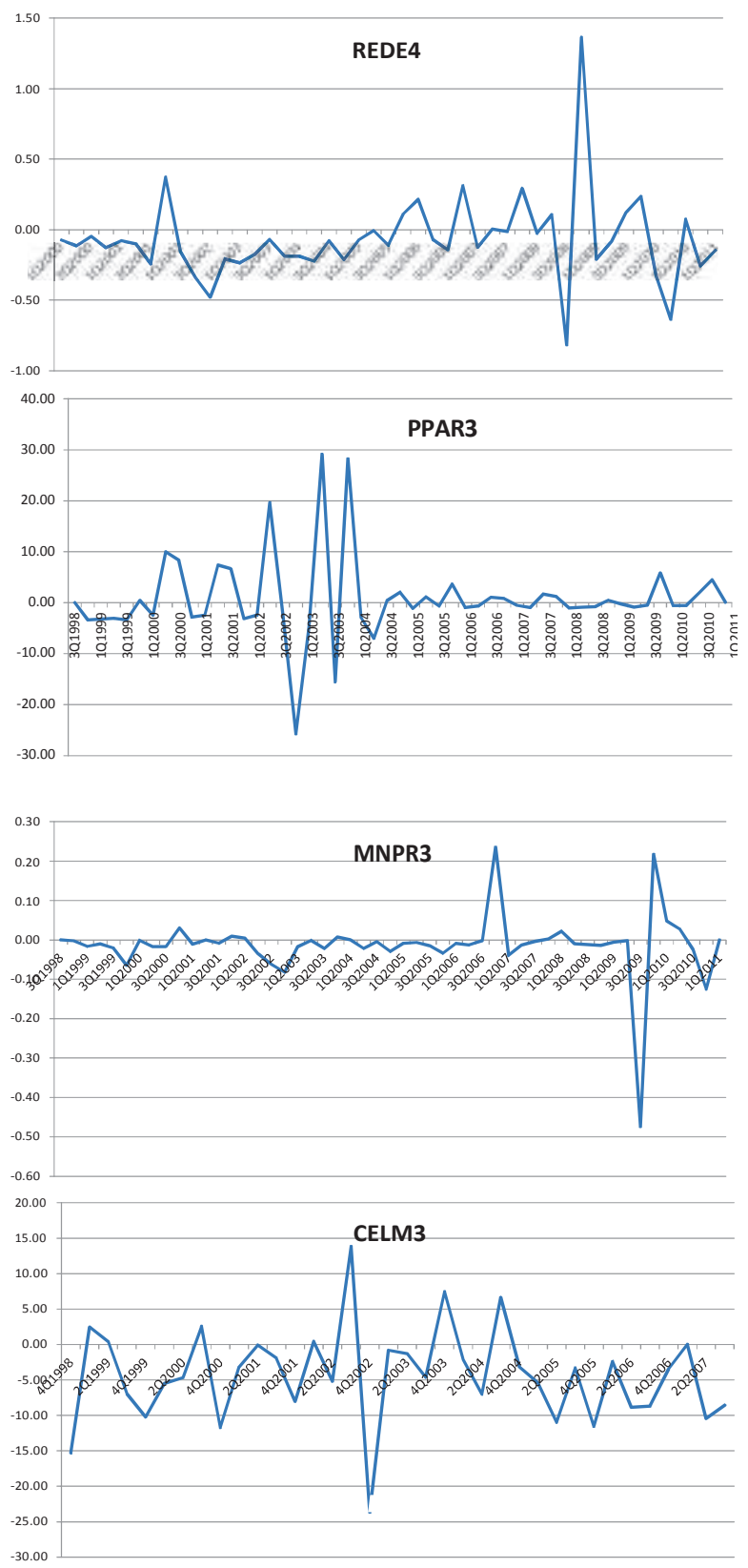

Figure 1: Earnings time-series behavior for companies with negative parameters REDE4, PPAR3, MNPR3 and CELM3 are trading ticker for the selected firms

According to graphics of time-series of earnings, in all cases a high shock in earnings can be observed. Firms represented by REDE4, MNPR3 and CELM3 show long periods of negative earnings. Hence, it is possible to interpret negative earnings (losses) persistence, meaning that some negative shock became permanent in the time-series. In all cases, positive high shocks were merely transitory, followed, in sequence, by negative earnings. PPAR3 case illustrates the period of high instability faced by some firms in Brazil given the international crisis (Argentina default) and local political instability (during the presidential election of 2002). 


\subsection{Cross-sectional tests for differences in persistence}

The second step in this paper aims to test two possible determinants for differences in earnings persistence. The first is the size of company and the second is the level of corporate governance practices.

In order to test the first hypothesis that relates earnings persistence and size, three different measures of size is used: total assets, total revenues and market capitalization. Since some companies do not have the entire period (i.e. some companies stopped their activities or were object of mergers and acquisitions and do not have recent data), we use the values of last information available, what induces a noise in the test since we are comparing data from different periods. In order to reduce this bias we estimated three quartiles $\left(25^{\text {th }}, 50^{\text {th }}\right.$ and $\left.75^{\text {th }}\right)$ to divided firms into four groups according to the size criteria.

Tests of mean differences were performed in order to check for differences in persistence between groups according to size. Given the lack of space, it is only presented results for size measured by the total asset in Table 4 . Other size measures reported similar conclusions.

Table 4: Mean test for differences in persistence parameters according to size (total assets)

\begin{tabular}{|c|c|c|c|c|c|c|c|c|}
\hline & \multirow[b]{2}{*}{$\mathrm{N}$} & \multirow[b]{2}{*}{ Mean } & \multirow[b]{2}{*}{$\begin{array}{c}\text { Std. } \\
\text { Deviation }\end{array}$} & \multirow[b]{2}{*}{$\begin{array}{l}\text { Std. } \\
\text { Error }\end{array}$} & \multicolumn{2}{|c|}{$\begin{array}{l}95 \% \text { Confidence } \\
\text { Interval for Mean }\end{array}$} & \multirow[b]{2}{*}{ Minimum } & \multirow[b]{2}{*}{ Maximum } \\
\hline & & & & & $\begin{array}{l}\text { Lower } \\
\text { Bound }\end{array}$ & $\begin{array}{l}\text { Upper } \\
\text { Bound }\end{array}$ & & \\
\hline Small & 67 & 0.1244 & 0.2414 & 0.0294 & 0.0655 & 0.1832 & -0.4308 & 0.7114 \\
\hline Medium-Small & 68 & 0.1577 & 0.2543 & 0.0308 & 0.0962 & 0.2193 & -0.4335 & 0.7246 \\
\hline Medium-Large & 68 & 0.2251 & 0.2590 & 0.0314 & 0.1624 & 0.2878 & -0.3775 & 0.7451 \\
\hline Large & 68 & 0.2554 & 0.2292 & 0.0277 & 0.2000 & 0.3109 & -0.3970 & 0.6771 \\
\hline Total & 271 & 0.1909 & 0.2504 & 0.0152 & 0.1609 & 0.2208 & -0.4335 & 0.7451 \\
\hline \multicolumn{9}{|c|}{ F-Statistics: 4.035} \\
\hline
\end{tabular}

F-Statistics reject the null hypothesis of same means between groups.

Based on the results presented in Table 4, it is indicated that the parameter of earnings persistence is different for firms with different sizes, that is the means of the persistence parameter is different among groups $(p<0,01)$. By observing the means for each group, the results indicate that larger firms present higher parameters of earnings persistence. Therefore, consistently with Lev (1983), we find support for our first hypothesis.

The second hypothesis predicts the relationship between earnings persistence and level of corporate governance. Firms were divided into four groups according to the listing 
level of corporate governance proposed by BM\&FBOVESPA (Sao Paulo Stock Exchange). The four groups consist of Bovespa New Market (NM), which is the most complete and high quality level of corporate governance; the second is Level 1 (N1), which is the second most advanced level of corporate governance; the third is Level 2 (N2), which is the less advanced corporate governance levels; and Trad. is the traditional listing process with few (or no) corporate governance practices. Number of companies in each listing corporate governance level was previous presented in Table 1.

Table 5: Mean test for differences in persistence parameters according to corporate governance levels

\begin{tabular}{|c|c|c|c|c|c|c|c|c|}
\hline & \multirow[b]{2}{*}{$\mathrm{N}$} & \multirow[b]{2}{*}{ Mean } & \multirow[b]{2}{*}{$\begin{array}{c}\text { Std. } \\
\text { Deviation }\end{array}$} & \multirow[b]{2}{*}{$\begin{array}{l}\text { Std. } \\
\text { Error }\end{array}$} & \multicolumn{2}{|c|}{$\begin{array}{l}95 \% \text { Confidence } \\
\text { Interval for Mean }\end{array}$} & \multirow[b]{2}{*}{ Minimum } & \multirow[b]{2}{*}{ Maximum } \\
\hline & & & & & $\begin{array}{l}\text { Lower } \\
\text { Bound }\end{array}$ & $\begin{array}{l}\text { Upper } \\
\text { Bound }\end{array}$ & & \\
\hline Trad. & 208 & 0.1699 & 0.2549 & 0.0177 & 0.1350 & 0.2047 & -0.4335 & 0.7451 \\
\hline N2 & 6 & 0.3272 & 0.1851 & 0.0756 & 0.1330 & 0.5215 & 0.1517 & 0.5915 \\
\hline N1 & 27 & 0.2266 & 0.2538 & 0.0489 & 0.1261 & 0.3270 & -0.1712 & 0.7026 \\
\hline NM & 30 & 0.2776 & 0.2010 & 0.0367 & 0.2026 & 0.3527 & -0.1413 & 0.6976 \\
\hline Total & 271 & 0.1909 & 0.2504 & 0.0152 & 0.1610 & 0.2209 & -0.4335 & 0.7451 \\
\hline
\end{tabular}

F-Statistics reject the null hypothesis of same means between groups.

According to Table 5, groups have different persistence parameter means at $10 \%$ level. Results in Table 5 do not make possible to strongly confirm that higher levels of corporate governance present higher persistence parameters, first because of the significance level (i.e. null hypothesis of same means cannot be rejected at $5 \%$ level), and second because of the means' magnitude for each group.

It is possible to see that NM firms have higher persistence parameter $(0.2776)$ than N1 firms (0.2266). On the other extreme, traditional system of listing (Trad.), with weak or none corporate governance standards, shows the lower persistence parameter $(0.1699)$, what, in part confirm previous expectation of higher corporate governance level is associated to higher persistence parameters. However, because of N2 group presents the highest mean (0.3272), it is not possible to strongly confirm our hypothesis. It may be that the small number of companies in group N2 (6 firms) makes conclusion not strongly significant.

In order to further investigate this issue, we divided firm into two groups: firms with listed corporate governance levels (NM, N1 and N2 firms) and firms with traditional listing (Trad.). The first group yields 63 firms and second group 208. We performed test 
for significance mean differences. Table 6 report the means for the two groups and it is possible to infer that firms with differentially corporate governance levels (special listing NM, N1 and N2) have a higher persistence parameter in average.

Table 6: Mean test for differences in persistence parameters according to corporate governance levels

\begin{tabular}{|c|c|c|c|c|}
\hline Groups of firms & $\mathrm{N}$ & Mean & $\begin{array}{c}\text { Std. } \\
\text { Deviation }\end{array}$ & $\begin{array}{l}\text { Std. Error } \\
\text { Mean }\end{array}$ \\
\hline Traditional listing & 208 & 0.1698 & 0.2548 & 0.0176 \\
\hline Firms with special listing (NM, N1 and N2) & 63 & 0.2604 & 0.2230 & 0.0281 \\
\hline Equal variances assumed: & F-Statistics: -2.541 & \multicolumn{3}{|c|}{ Sig.: 0.012} \\
\hline Equal variances not assumed: & F-Statistics: -2.728 & \multicolumn{3}{|c|}{ Sig.: 0.007} \\
\hline
\end{tabular}

F-Statistics reject the null hypothesis of same means between groups.

We additionally test differences between the three special listing groups (NM, N1 and N2). However, it is not possible to statistically confirm differences between the three groups with higher levels of corporate governance.

\section{CONCLUSIONS}

Given the different roles that the parameter of earnings persistence can play, it seems to be relevant to understand how persistent earnings of Brazilian listed firms are and identify some of the potential determinants of earnings persistence, namely firm size and corporate governance standard.

By collecting quarterly earnings data, we document considerable variability in firmspecific quarterly earnings persistence. We show that most of the firms present earnings persistence not significantly different from zero and, puzzling, some firms present significant negative earnings persistence. Moreover, we found noticeable lower earnings persistence than those found in previous studies applied to the American listed firms.

Our results also suggest that the firm size seems to be an important determinant of the parameter of earnings persistence. Using different measures for size - total assets, total revenues and market capitalization-we consistently obtain support for our first hypothesis indicating that the parameter of earnings persistence is higher for larger firms.

Finally, earnings persistence is higher for firms with listing level of corporate governance standards when compared with traditional listing companies. However, we do not find strong support that the parameter of earnings persistence is higher for firms with the higher corporate governance standards (NM in comparison to the other two levels of corporate governance standards), partially supporting our second hypothesis. 
Given the considerable variability in firm-specific earnings persistence, the main conclusion of this paper is that accounting earnings must be considered with cautions when used for both valuation and stewardship purposes, especially, for smaller firms and those with lower corporate governance standards.

While we tried to discuss some possible reasons for these results, it seems necessary to develop more research in order to understand determinants of earnings persistence for Brazilian listed companies; what should be of considerable interest to standard setters when they consider alternative reporting standards that might have an impact on firms' earnings persistence.

\section{REFERENCES}

BABER, W. R.; KANG, S.; KUMAR, K. R. Accounting earnings and executive compensation: the role of earnings persistence. Journal of Accounting and Economics, $v$. 25, n. 2, p. 169-193, maio 1998.

BAGINSKI, S. P. et al. The relationship between economic characteristics and alternative annual earnings persistence measures. The Accounting Review, Vol. 74, No. 1, p. 105$120,1999$.

BAGINSKI, S. P. et al. A time-series approach to measuring the decline in quarterly earnings persistence. Advances in Accounting, v. 20, p. 23-42, 2003.

BROWN, L. D. Earnings forecasting research: its implications for capital markets research. International Journal of Forecasting, v. 9, n. 3, p. 295-320, 1993.

CHRISTENSEN, P. O.; FELTHAM, G. A.; SABAC, F. A contracting perspective on earnings quality. Journal of Accounting and Economics, v. 39, n. 2, p. 265-294, jun. 2005.

COELHO, A.C.; AGUIAR, A. B.; LOPES, A. L. Relationship between abnormal earnings persistence, industry structure, and market share in Brazilian public firms. Brazilian Administration Review, v. 8, n. 1, p. 48-67, jan./mar. 2011.

COLLINS, D. W.; KOTHARI, S. P. An analysis of intertemporal and cross-sectional determinants of earnings response coefficients. Journal of Accounting and Economics, v. 11, n. 2-3, p. 143-181, jul. 1989.

DECHOW, P. M.; SLOAN, R. G. Executive incentives and horizon problems. Journal of Accounting and Economics, v. 14, n. 1, p. 51-89, mar. 1991.

DECHOW, P. M.; GE, W.; SCHRAND, C. Understanding earnings quality: a review of the proxies, their determinants and their consequences. Journal of Accounting and Economics, v. 50, n. 2-3, p. 344-401, dez. 2010. 
EASTON, P. D.; ZMIJEWSKI, M. E. Cross-sectional variation in the stock market response to accounting earnings announcement. Journal of Accounting and Economics, v. 11, n. 2-3, p. 117-141, jul. 1989.

FOSTER, G. Quarterly accounting data: time-series properties and predictive-ability results. The Accounting Review, v. 52, n. 1, p. 1-21, jan. 1977.

KOTHARI, S. P. Capital markets research in accounting. Journal of Accounting and Economics, v. 31, n. 1-3, p. 105-231, set. 2001.

KORMENDI, R.; LIPE, R. Earnings innovations, earnings persistence and stock returns. Journal of Business, v. 60, n. 3, p. 323-345, jul. 1987.

LEV, B. Some economic determinants of time-series properties of earnings. Journal of Accounting and Economics, v. 5, n. 1, p. 31-48, abr. 1983.

LIPE, R. The relation between stock returns and accounting earnings given alternative information. The Accounting Review, Vol. 65, No. 1, p. 49-71, jan. 1990.

MENDENHALL, R. R. How naïve is the market's use of firm-specific earnings information? Journal of Accounting Research, Vol. 40, No. 3, p. 841-863, jun. 2002.

MILLER, M.; ROCK, K. Dividend policy under asymmetric information. Journal of Finance, v. 40, n. 4, p. 1031-1052, set. 1985.

OHLSON, J. A. Earnings, book values, and dividends in equity valuation. Contemporary Accounting Research, v. 11, n. 2, p. 661-687, Spring 1995.

PIMENTEL, R. C.; LIMA, I. S. Time-series properties of earnings and their relationship with stock prices in Brazil. Business and Economics Research Journal, Vol. 1, No. 4, p. 43-65, 2010.

ŞABAC, F. Dynamic incentives and retirement. Journal of Accounting and Economics, v. 46, n. 1, p. 172-200, set. 2008.

SILVA, A. C.; SUBRAHMANYAM, A. Dual-class premium, corporate governance, and the mandatory bid rule: evidence from the Brazilian stock market. Journal of Corporate Finance, v. 13, n. 1, p. 1-24, mar. 2007.

ZHAO, R.; MILLET-REYES, B. Ownership structure and accounting information content: evidence from France. Journal of International Financial Management and Accounting, Vol. 18, No. 3, p. 223-246, Autumn 2007. 